\title{
WYZNANIA - PAŃSTWO - NARÓD W II RZECZYPOSPOLITEJ
}

\section{Tadeusz Stegner}

(10) http://orcid.org/0000-0002-3249-0214

Uniwersytet Gdański

\section{ABSTRACT \\ DENOMINATIONS - STATE - NATION IN THE SECOND POLISH REPUBLIC}

The Second Republic of Poland was a country of multiple religions, where the followers of Roman Catholicism, Greek Catholics, Orthodox, Protestants and Jews lived alongside each other. In the reborn Poland, the constitution of the commonwealth was the framework that determined religious policy. All citizens were guaranteed freedom of religion, as well as the right to public and private religious practices. State authorities tried to apply the principle of equality and balance to the various religious associations in their mutual relations. The authorities did not give in to pressure, mainly from the Roman Catholic side, striving to strengthen its dominant position, and they tried to preserve the religious peace in the country. Moreover, due to the national-religious structure of the Second Republic both the ruling class and the broader circles of Polish society assessed individual religious associations through the prism of the relation of a given religious minority to the Polish state and its national interests. Subsequent governments, starting from 1918, tried to prevent (rather without success) religious organizations from becoming centers of nationalistic activity for Germans, Ukrainians, and Belarusians, which was usually directed against Poland. They also attempted to influence the internal affairs of churches and religious associations of national minorities through legal regulations, and to accelerate their possible Polonization.

Keywords: religion, state, nation, Second Republic of Poland.

Słowa kluczowe: religia, państwo, naród, II Rzeczpospolita.

Wielowyznaniowość była trwałym elementem krajobrazu II Rzeczypospolitej. Według danych statystycznych z 1931 roku 64,8\% ludności było wyznania rzymskokatolickiego, 10,4\% greckokatolickiego, 11,8\% prawosławnego, 9,8\% mojżeszowego, $2,6 \%$ ewangelickiego i $0,5 \%$ innego ${ }^{1}$. Na temat kwestii wyznaniowych powstało

${ }^{1}$ Historia Polski $w$ liczbach, t. 1, Warszawa 1994, s. 161. W spisach nie uwzględniano osób bezwyznaniowych.

Adres do korespondencji: stegner@interia.pl 
wiele prac o charakterze zarówno syntetycznym, jak i przyczynkarskim, poruszających różne aspekty szeroko rozumianej problematyki religijnej. W niniejszym artykule chciałbym podzielić się z czytelnikami pewnymi uwagami i przemyśleniami dotyczącymi relacji poszczególnych związków wyznaniowych z instytucjami państwowymi i narodowymi.

Wydarzenia I wojny światowej, a w jej rezultacie powstanie niepodległego państwa polskiego w sposób znaczący wpłynęły na sytuację poszczególnych związków wyznaniowych. Wobec odradzającej się Rzeczypospolitej zajęły one zróżnicowaną postawę. Arcybiskup warszawski Kościoła rzymskokatolickiego Aleksander Kakowski w swoim pamiętniku zanotował: „Czasu wielkiej wojny [...] dokonało się dzieło sprawiedliwości Bożej. Polska w niewoli odpokutowała za grzechy przeszłości, przebudziła się $\mathrm{z}$ wiekowego letargu. $\mathrm{Z}$ ducha i myśli narodu poczęta, znowu zaczęła żyć odmłodzona, odrodzona"2. Kościół rzymskokatolicki, grupujący zdecydowaną większość Polaków, z nadzieją, ale i pewnymi obawami odniósł się do listopadowych wydarzeń 1918 roku. Liczono, że zniesione zostaną ograniczenia nałożone na ten Kościół przez władze rosyjskie i niemieckie. Obawiano się jednak radykalizmu społecznego partii lewicowych i ludowych, postulatów zmierzających do ograniczenia roli Kościoła w życiu politycznym, laicyzacji życia społecznego. „Liberalizm, skrajny radykalizm, materializm sączyły się do duszy polskiej. [...] Uderzano w Kościół, potępiano duchowieństwo katolickie"3 - pisał arcybiskup.

Także Tymczasowy Naczelnik Józef Piłsudski w 1918 roku nie cieszył się zaufaniem kręgów kościelnych. Niechęć części hierarchów wiązała się z jego socjalistyczną przeszłością, zmianą na kilkanaście lat wyznania na ewangelicko-augsburskie oraz faktem, że wielu duchownych wspierało obóz narodowo-demokratyczny, a więc przeciwników piłsudczyków. Warto przypomnieć, że gdy oddziały Piłsudskiego w 1914 roku wkroczyły do Kielc, tamtejszy biskup Augustyn Łosiński odmówił im poparcia, podobnie podległe mu duchowieństwo ${ }^{4}$.

Cerkiew greckokatolicka w Galicji, na której czele stał Ukrainiec z wyboru, Andrzej hrabia Szeptycki, też wspierała nowo tworzące się państwo, ale ukraińskie, czyli Zachodnio-Ukraińską Republikę Ludową. Podczas walk o Lwów w listopadzie 1918 roku metropolita halicko-lwowski Szeptycki wchodził w skład Ukraińskiej Rady Narodowej, organu przedstawicielskiego tworzącej się republiki. Po zakończeniu działań wojennych wyjechał z kraju i działał na arenie międzynarodowej, między innymi w Rzymie, w Stanach Zjednoczonych, na rzecz niepodległości Ukrainy 5 .

${ }^{2}$ A. Kakowski, Z niewoli do niepodległości. Pamiętniki, wstęp J. Glemp, red. i oprac. T. Krawczak, R. Świętek, Kraków 2000, s. 800.

${ }_{3}^{3}$ Ibidem, s. 803. Por. M. P i l la, Udziat duchowieństwa w polskim życiu politycznym w latach 1914 1924, Lublin 1994.

${ }^{4}$ T. Stegner, Józef Piłsudski: katolik, ewangelik, czy...? [w:] O niepodległości ekumenicznie. Wyznawcy różnych Kościołów dla Rzeczypospolitej (1918-1939), red. S. Bober, S. Żurek, Lublin 2018, s. 75-88.

${ }^{5}$ E. Koko, Metropolita Andrzej Szeptycki a państwo polskie [w:] Metropolita Andrzej Szeptycki, red. T. S te gn er, Gdańsk 1995, s. 55-69. 
Powstanie państwa polskiego nie budziło entuzjazmu w kręgach prawosławnych. Cerkiew prawosławna, podpora władzy rosyjskiej na ziemiach polskich, spotykała się z wrogością ze strony znacznej części społeczeństwa polskiego. Jej struktury organizacyjne w wyniku zawieruchy wojennej lat 1914-1918 uległy rozbiciu ${ }^{6}$. Pozostała w Polsce część hierarchii kościelnej, prawie wyłącznie Rosjanie, uznawała Cerkiew prawosławną w Polsce za część Cerkwi rosyjskiej, stała na stanowisku istnienia „Jednej i niepodzielnej Rosji”, a w świątyniach modlono się za „Wielką dumną i świętą Rosję" W wielu miastach dochodziło do burzenia budynków cerkiewnych uznawanych za symbol rosyjskiej dominacji z czasów zaborów, najbardziej głośne było rozebranie w latach 1922-1924 wielkiego Soboru św. Aleksandra Newskiego na placu Saskim w Warszawie ${ }^{8}$.

Wobec faktu powstania niepodległego państwa polskiego zróżnicowana była postawa środowisk protestanckich. Polscy ewangelicy, zwłaszcza w dawnym Królestwie Polskim i na Śląsku Cieszyńskim, aktywnie wspierali polskie dążenia narodowe. Zwierzchnik Kościoła Ewangelicko-Augsburskiego ksiądz Juliusz Bursche działał na rzecz przyłączenia tak zwanych kresów polsko-ewangelickich do Rzeczypospolitej ${ }^{9}$. W tej sprawie udał się jako przedstawiciel rządu polskiego na początku 1919 roku do Paryża na konferencję pokojową. Brał udział w toczących się negocjacjach $^{10}$. Natomiast niemieccy protestanci, zwłaszcza z terenów Wielkopolski i Pomorza, próbowali nie przyjmować do wiadomości faktu powstania niepodległego państwa polskiego i jego zwierzchności nad Kościołem Ewangelicko-Unijnym. 12 listopada 1918 roku generalny superintendent tego Kościoła skierował list do pastorów, w którym zapewniał o pełnej jedności z narodem i państwem niemieckim. Potępił też powstanie wielkopolskie ${ }^{11}$.

Wyznawcy judaizmu, czyli ludność żydowska, w burzliwych latach 1918-1921, gdy ciągle, zwłaszcza na wschodnich rubieżach, zmieniała się władza, starali zachowywać się tak, by nie dawać powodów do represji ze strony polskiej, ukraińskiej czy radzieckiej, co nie zawsze im się udawało. Dochodziło do pogromów. Jak pisał Jerzy Tomaszewski: „Obydwie strony podejrzewały Żydów o sprzyjanie przeciwnikowi, co pociągało tragiczne konsekwencje" ${ }^{12}$.

${ }^{6}$ W. Kołbuk, Cerkiew prawosławna w Polsce międzywojennej, Lublin 2013, s. 43.

${ }^{7}$ M. Papierzyńska-Turek, Kościót prawosławny w Polsce $w$ latach 1918-1927, „Dzieje Najnowsze" 1976, nr 3.

${ }^{8}$ A. Mironowicz, Prawostawni a odbudowa państwa polskiego(1918-1939) [w:] Oniepodległości ekumenicznie..., s. 39.

${ }^{9}$ Mianem kresy polsko-ewangelickie określano tereny Śląska Cieszyńskiego, Mazur oraz Śląska Górnego i Śląska Opolskiego zamieszkałe w znacznym stopniu przez ludność polsko-ewangelicką.

${ }^{10}$ T. Stegner, Kościót Ewangelicko-Augsburski u zarania II Rzeczypospolitej [w:] Ewangelicy w Niepodległej, red. E. Jóźwiak, M. Kars ki, Warszawa 2018, s. 19-32.

${ }^{11}$ E. A l a bru dzińs k a, Religia i polityka. Stosunek Kościołów ewangelickich do państwa polskiego w latach 1918-1939 [w:] O niepodlegtości ekumenicznie..., s. 151.

${ }^{12}$ Chodzi o stronę polską i radziecką. J. Tomaszewski, Niepodległa Rzeczpospolita [w:] Najnowsze dzieje Żydów w Polsce w zarysie (do 1950 roku), Warszawa 1993, s. 147. Por. G. Ga uden, Lwów - kres iluzji: opowieść o pogromie listopadowym 1918 r., Kraków 2019. 
Manifest Tymczasowego Rządu Republiki Polskiej z 7 listopada 1918 roku zapowiadał: „Całkowite polityczne i obywatelskie równouprawnienie wszystkich obywateli bez różnicy pochodzenia, wiary, narodowości"13. W będącej rezultatem kompromisu między propozycjami lewicy i prawicy konstytucji z 1921 roku sprawom wyznaniowym poświęconych było kilkanaście artykułów. Wszystkim obywatelom zagwarantowano wolność wyznania, prawo publicznego i prywatnego wykonywania praktyk religijnych (art. 111). Nikt też nie mógł być zmuszany do udziału w czynnościach i obrzędach religijnych, jeśli nie podlegał władzy rodzicielskiej bądź opiekuńczej (art. 112). Były to dość liberalne rozwiązania, nieodbiegające od ówczesnych standardów europejskich.

Odmiennie jednak niż innych związków wyznaniowych określona została pozycja Kościoła rzymskokatolickiego. W artykule 114 czytamy: „Wyznanie rzymskokatolickie, będące religią przeważającej większości narodu zajmuje w Państwie naczelne stanowisko wśród równouprawnionych wyznań”14. W ten sposób Kościół rzymskokatolicki uznany został za primus inter pares. Teoretycznie takie sformułowanie nie dawało Kościołowi żadnych uprawnień ponad te, które miały inne związki wyznaniowe, z wyjątkiem przywilejów honorowych, na przykład pierwszeństwo duchownych katolickich przed przedstawicielami innych wyznań w czasie oficjalnych uroczystości państwowych. Jednak w praktyce z reguły władze państwowe interpretowały „naczelne stanowisko” Kościoła rzymskokatolickiego w sposób korzystny dla niego. Przykładowo podczas uroczystości związanych z odsłonięciem Grobu Nieznanego Żołnierza w Warszawie w dniu 2 listopada 1925 roku arcybiskup rzymskokatolicki Kakowski sprzeciwił się obecności przedstawicieli innych wyznań na tych obchodach. Władze państwowe uległy żądaniom hierarchy i wyznaczono im miejsce wśród delegatów obcych państw. Na znak protestu członkowie władz Kościoła Ewangelicko-Augsburskiego i innych wyznań wycofali się z udziału w tych uroczystościach ${ }^{15}$.

We wspomnianym już art. 114 stwierdzono, że Kościół rzymskokatolicki „rządzi się własnymi prawami”, a „stosunek Państwa do Kościoła będzie określony na podstawie układu ze Stolicą Apostolską, który podlega ratyfikacji przez Sejm" ${ }^{16}$. Konkordat został zawarty w 1925 roku i dawał dużo swobody działania Kościołowi katolickiemu oraz ograniczał możliwość ingerencji władz państwowych w jego sprawy wewnętrzne ${ }^{17}$. Jednak te rozstrzygnięcia nie do końca zadowalały hierarchów.

Relacje państwo - Kościół rzymskokatolicki w dwudziestoleciu międzywojennym układały się w miarę poprawnie, choć nie brakowało pól konfliktów i wzajemnych oskarżeń. Pamiętajmy, że w kręgach przywódczych II RP, zwłaszcza w czasach

${ }_{13}$ Manifest Tymczasowego Rzadu Republiki Polskiej z 7 XI 1918 r. [w:] Powstanie II Rzeczypospolitej. Wybór dokumentów, Warszawa 1981, s. 30.

${ }^{14}$ Konstytucja marcowa, oprac. A. B urd a, Lublin 1983, s. 93.

15 J. Kłaczkow, Kościót Ewangelicko-Augsburski w Polsce w latach 1918-1939, Torun 2019, s. $121-122$.

${ }^{16}$ Konstytucja marcowa, s. 93.

${ }_{17}$ G. Bujak, Państwo a Kościoły i zwiazki wyznaniowe w II Rzeczypospolitej (1918-1939) [w:] O niepodległości ekumenicznie..., s. 13-20. 
sanacyjnych, dominowały osoby ukształtowane w duchu pozytywistycznym, nierzadko o socjalistycznej przeszłości. Pierwszy prezydent Gabriel Narutowicz był w zasadzie ateistą, jego następcy Stanisław Wojciechowski i Ignacy Mościcki nie manifestowali swoich poglądów w kwestiach religijnych, choć w uroczystościach o charakterze państwowo-religijnym uczestniczyli. Józef Piłsudski raz był ewangelikiem, raz katolikiem, interesował się spirytyzmem. Marszałek rozumiał jednak znaczenie religii w życiu społecznym i chociaż nie był osobą specjalnie religijną, nawet będąc zaangażowany w ruch socjalistyczny, przeciwko religii jako takiej nie występował. Doceniał też rolę Kościoła rzymskokatolickiego w społeczeństwie polskim i starał się zachowywać z nim w miarę poprawne stosunki, nie tworzyć pól konfliktów, ale też zbytnio mu nie ulegać. W tym względzie Marszałek wykazywał się dużym pragmatyzmem. Mimo że zamach majowy 1926 roku został krytycznie przyjęty przez większość duchowieństwa rzymskokatolickiego sprzyjającego z reguły Narodowej Demokracji, to Piłsudski dbał, by stosunki z Kościołem rzymskokatolickim były poprawne. W 1930 roku powiedział: „dopóki ja żyję, będę mimo wszystko utrzymywał dobre stosunki z kościołem"18. Także kontakty ze Stolicą Apostolską były utrzymywane na odpowiednim poziomie, zwłaszcza z papieżem Piusem XI, który miał powiedzieć: „Póki Piłsudski przy sterze, Kościołowi katolickiemu w Polsce nic się nie stanie"19.

Zdarzały się jednak sytuacje konfliktowe. Przykładowo po śmierci Marszałka, po uroczystościach pogrzebowych władze sanacyjne zarzuciły niektórym biskupom, że niedostatecznie uczcili pamięć Piłsudskiego, na przykład biskup kielecki odmówił uroczystego celebrowania mszy świętej w intencji Marszałka ${ }^{20}$. Józef Piłsudski został pochowany na Wawelu w krypcie św. Leonarda, natomiast w dwa lata później, 23 czerwca 1937 roku arcybiskup krakowski Adam Sapieha zarządził przeniesienie trumny ze zwłokami do nowo zbudowanej krypty pod Wieżą Srebrnych Dzwonów, znajdującej się właściwie poza obrębem katedry wawelskiej. Podnoszony był argument, że Wawel jest miejscem pochówku królów. Te decyzje wywołały oskarżenia ze strony obozu rządzącego o zbezczeszczenie zwłok Marszałka. Toczyła się burzliwa dyskusja na łamach prasy, a także na ulicach, wybito szyby w domu metropolity. Sapieha pozostał jednak nieugięty.

Z kolei władze kościelne zarzucały władzom państwowym niestabilną politykę w sprawach wyznaniowych. Wielokroć wzmiankowany arcybiskup Kakowski pisał: „Każdy nowy rząd, każdy nowy minister wyznań religijnych i oświecenia publicznego rządził się własnymi zasadami. [...] Nie było więc polityki państwowej, tylko polityka poszczególnych gabinetów i ministrów; niestała, zmienna, ulegająca ubocznym, nieraz obcym wpływom" ${ }^{21}$. Kontrowersje budziła też obsada stanowiska ministra wyznań religijnych i oświecenia publicznego nadzorującego kwestie religijne i działania niektórych z nich. Zwracano uwagę, że często tę godność sprawowali

${ }^{18}$ A. Micew ski, Z geografii politycznej II Rzeczpospolitej, Kraków 1966, s. 255-256.

19 J. Warszawski, Studia nad wyznaniowościa religijną marszałka Józefa Piłsudskiego, Londyn 1978, s. 47.

20 Ibidem, s. 279.

${ }^{21}$ A. Kakowski, op. cit., s. 883. 
niekatolicy bądź osoby niewierzące czy związane z masonerią, co miało negatywnie wpływać na stosunki państwo - Kościół rzymskokatolicki ${ }^{22}$. Ewangelikiem reformowanym był minister tego resortu w latach 1929-1931 Sławomir Czerwiński.

Nie zdobyła zaufania dostojników Kościoła katolickiego nowa elita polityczna, która w pełni objęła władzę po przewrocie majowym. Nieco złośliwie pisał o niej arcybiskup warszawski Kakowski:

Narzucona [...] kasta urzędników partyjnych, z nizin społecznych, bez ogłady towarzyskiej, wysunęła się na czoło społeczeństwa. Ich starych żon, bez ogłady, prostych kucharek, nie można było pokazać na salonach zamku królewskiego; trzeba było je zamienić na młode eleganckie damy. Stąd pęd do rozwodów i rozwody kalwińskie, luterskie, prawosławne i inne ${ }^{23}$.

Dość napięte były stosunki władz polskich z wyznawcami obrządku greckiego Kościoła katolickiego. Państwo traktowało go jako ośrodek ukraińskiej irredenty. Z tych też względów rząd polski nie zgodził się, by Kościół greckokatolicki prowadził działalność wśród prawosławnych Ukraińców mieszkających na Wołyniu. Nie dopuszczono też do wykonywania jurysdykcji przez metropolitę na terenie Polski poza granicami archidiecezji lwowskiej oraz diecezji przemyskiej i stanisławowskiej, czyli dawnej Galicji. W 1923 roku arcybiskup Szeptycki, powracający do kraju po dwuletniej nieobecności, był nawet przez jakiś czas internowany. Interweniował w jego sprawie u ministra spraw zagranicznych Mariana Seydy arcybiskup warszawski Kakowski ${ }^{24}$. Stałym źródłem konfliktów była sprawa obsady stanowisk duszpasterskich. Władze polskie, na mocy postanowień konkordatu i za aprobatą władz Kościoła rzymskokatolickiego, odmawiały zatwierdzenia bądź żądały ustąpienia z urzędu duchownych zaangażowanych $\mathrm{w}$ ukraińską działalność narodową. Księża uniccy występowali przeciwko antyukraińskim poczynaniom strony polskiej, na przykład ograniczaniu praw języka ukraińskiego w szkołach, w prowadzeniu akt parafialnych, pacyfikacji Galicji Wschodniej w 1930 roku czy akcji burzenia cerkwi prawosławnych na Chełmszczyźnie w 1938 roku²5.

Nie sprawiał większych kłopotów władzom Kościół katolicki obrządku ormiańskiego, niewielki, liczący kilka tysięcy wiernych, grupujący Polaków ${ }^{26}$, choć niektóre wypowiedzi w duchu narodowo katolickim jego zwierzchnika arcybiskupa Józefa Teodorowicza budziły kontrowersje, na przykład w sprawie uznania religii katolickiej za panującą.

W II RP, oprócz rzymskiego, greckiego i ormiańskiego, funkcjonował jeszcze obrządek wschodniosłowiański. Należały do niego w 1938 roku czterdzieści trzy

${ }^{22}$ Ibidem, s. 887.

${ }^{23}$ Ibidem, s. 804. Por. P. Les zc zyński, Stosunki państwo-Kościót w koncepcjach oraz praktyce rządów obozu piłsudczykowskiego, Gorzów Wielkopolski 2008.

${ }^{24}$ Ibidem, s. 884.

${ }^{25}$ S. Stępień, Życie religijne społeczności ukraińskiej w Drugiej Rzeczypospolitej [w:] PolskaUkraina. 1000 lat sąsiedztwa. Studia z dziejów chrześcijaństwa na pograniczu etnicznym, t. I, red. S. Stępi ień, Przemyśl 1990, s. 207-229; T. Śliw a, Kościót greckokatolicki w Polsce w latach 19191939 [w:] Kościół w II Rzeczypospolitej, red. Z. Zi eliń ski, S. Wilk, Lublin 1980, s. 149-165.

${ }^{26}$ K. S to pka, Ormianie w Polsce dawnej i dzisiejszej, Kraków 2000, rozdz. W Polsce odrodzonej, s. $100-104$. 
parafie, blisko 17000 wiernych, głównie na Podlasiu i Polesiu ${ }^{27}$. Z inicjatywy biskupów katolickich ze wschodnich obszarów Rzeczypospolitej, między innymi biskupa podlaskiego Henryka Przeździeckiego, parafie te odłączyły się od prawosławia i zachowując własną liturgię i obrządek, przyłączyły się do Kościoła katolickiego. Była to niezbyt udana próba poszerzenia wpływów katolicyzmu na Wschodzie, swoista neounia. Inicjatywa ta nie spotkała się ze znaczącym poparciem ze strony władz państwowych.

Skomplikowane były relacje z Cerkwią prawosławną. Władze polskie w myśl zasady, że organy zwierzchnie związków wyznaniowych, poza katolickimi, nie powinny znajdować się poza granicami kraju, opowiadały się za jej odłączeniem się od Cerkwi moskiewskiej na drodze autokefalii. Mimo oporu części duchownych (ci, którzy byli przeciwni autokefalii, zostali usunięci z urzędów, internowani bądź osadzeni w klasztorach) uniezależnienie Cerkwi prawosławnej w Polsce zostało wprowadzone w życie, za zgodą patriarchy Konstantynopola, w 1924 roku. Skomplikowany był problem rewindykacji obiektów sakralnych przez Kościół rzymskokatolicki, który próbował nie tylko przywrócić swój poprzedni stan posiadania, ale go nawet rozszerzyć, co wywoływało wiele konfliktów. Usiłował nawet przejąć najbardziej znane sanktuarium prawosławne w Polsce w Poczajowie (ławra Zaśnięcia Matki Bożej w Poczajowie), ale władze państwowe się na to nie zgodziły. Szerokim echem, także i za granicą, odbiła się akcja burzenia przy użyciu sił policyjnych i wojskowych obiektów cerkiewnych na Chełmszczyźnie i Podlasiu w 1938 roku $^{28}$.

Cerkiew prawosławna była niejednolita pod względem narodowościowym. Zdecydowaną większość wiernych stanowili Ukraińcy i Białorusini, niewielki procent Rosjanie, którzy zajmowali jednak w Cerkwi wszystkie ważniejsze stanowiska. Władze państwowe z reguły wspierały rosyjskich hierarchów, obawiając się ukrainizacji czy białorutenizacji cerkwi, co byłoby sprzeczne z polskim interesem narodowym ${ }^{29}$. Pod koniec lat 30. doszło do unormowania sytuacji prawnej prawosławia. W 1938 roku prezydent Ignacy Mościcki podpisał dekret o stosunku państwa do Polskiego Autokefalicznego Kościoła Prawosławnego dający czynnikom rządowym dość duże możliwości ingerencji w sprawy wewnętrzne Cerkwi, w stopniu znacznie większym, niż miało to miejsce w przypadku innych wyznań ${ }^{30}$. Rządy, zwłaszcza sanacyjne, starały się ograniczyć działalność zarówno Cerkwi greckokatolickiej, jak

27 F. Rzemieniuk, Kościól katolicki obrządku bizantyjsko-słowiańskiego. Neounia, Lublin 1999, s. 139 .

${ }_{28}$ W. Kołbuk, op. cit., s. 91. W. Borszczewycz, Wolyńska polityka kościelna Drugiej Rzeczypospolitej a idea współpracy polsko-ukraińskiej, ,Biuletyn Ukrainoznawczy” 2000, nr 6, s. 96.

${ }^{29}$ Odmiennego zdania był wojewoda wołyński z lat 30. Henryk Józewski, który uważał, że ukrainizacja cerkwi może się przyczynić do polsko-ukraińskiego porozumienia, W. Mędrzecki, Województwo wotyńskie 1921-1939. Elementy przemian cywilizacyjnych, społecznych i politycznych, Wrocław 1998, s. 154.

30 R. Płoński, Chwila sacrum w życiu prawosławia w Drugiej Rzeczypospolitej [w:] Religia a społeczeństwo Drugiej Rzeczypospolitej, red. T. Stegner, Metamorfozy Społeczne, t. 5, Warszawa 2013. s. 169; W. Kołbuk, op. cit., s. 58-60. 
i prawosławnej do wschodnich terenów II RP. Józef Piłsudski miał mówić: „Do Bugu ani unia, ani prawosławie"s1.

W Polsce międzywojennej działało siedem kościołów protestanckich - dwa nieliczne, złożone głównie z Polaków kościoły ewangelicko-reformowane, tak zwana Jednota Warszawska i Jednota Wileńska, w dawnej Galicji Kościół Augsburskiego i Helweckiego wyznania w Małopolsce, grupujący tylko 5000 wiernych Kościół Ewangelicko-Luterański (staroluterski) w Polsce Zachodniej oraz najbardziej liczne i znaczące: Kościół Ewangelicko-Augsburski, Kościół Ewangelicki Unii Staropruskiej w Poznańskiem i na Pomorzu oraz Kościół Ewangelicki Unii Staropruskiej na Polskim Górnym Śląsku. Kościoły unijne skupiały głównie Niemców i ich sytuacja prawna przez cały okres międzywojenny nie była do końca uregulowana, a stosunki z polskimi władzami dość napięte ${ }^{32}$. Protestanci niemieccy byli niekiedy prześladowani i szykanowani przez obce zarówno pod względem narodowym, jak i wyznaniowym państwo polskie i jego obywateli.

Władze kościołów unijnych uważały II RP za twór „sezonowy”, liczyły na jego rozpad i ponowne przyłączenie ziem byłej dzielnicy pruskiej do Rzeszy. Sytuację, w jakiej znalazły się na mocy postanowień traktatu wersalskiego, uznawały za tymczasową. W związku z tym dążyły do zachowania łączności organizacyjnej z Kościołem macierzystym w Niemczech, a zwłaszcza z Naczelną Radą Kościelną w Berlinie. W 1920 roku, bez porozumienia z rządem polskim, doszło do wyodrębnienia się Kościoła ewangelicko-unijnego w Wielkopolsce i na Pomorzu, jednak kontakty z niemieckimi organami ewangelickimi nie ustały. Superintendent tegoż Kościoła, ksiądz Paul Blau, uważał, że „odłączenie kościoła unijnego od berlińskiej centrali będzie pierwszym krokiem do zagłady protestantyzmu w Polsce" ${ }^{33}$. Na postawę Kościołów unijnych wobec państwa polskiego niemały wpływ miały też stosunki polsko-niemieckie, $\mathrm{z}$ reguły $\mathrm{w}$ okresie międzywojennym dość napięte ${ }^{34}$. Wiele poczynań tych Kościołów, zwłaszcza w kwestii stosunków z państwem polskim, uzgadniane było z władzami niemieckimi w Berlinie. Dopiero po unormowaniu stosunków między Polską a Trzecią Rzeszą w 1934 roku nastąpiło pewne uspokojenie wzajemnych relacji, czego wyrazem było odprawianie w niektórych kościołach unijnych nabożeństw z okazji rocznicy odzyskania przez Polskę niepodległości ${ }^{35}$.

Największym protestanckim związkiem wyznaniowym był Kościół Ewangelicko-Augsburski liczący ponad 400000 wiernych, z czego około 1/3 stanowili Polacy. Kościół ten rozszerzył swoją działalność po 1918 roku na teren Śląska Cieszyńskiego, dawnych ziem zabranych, Krakowa, a także Wielkopolski i Pomorza, gdzie w latach 30. zaczęły powstawać polsko-ewangelickie zbory, co stało się źródłem konfliktu z Kościołem unijnym. Władzę w Kościele sprawowali polscy ewangelicy

${ }^{31}$ A. Kakowski, op. cit., s. 887.

32 E. A labrudzińs ka, Protestantyzm w Polsce w latach 1918-1939, Torun 2004, s. 70-89.

${ }_{33}$ J. Kłaczkow, Kościół Ewangelicko-Augsburski..., s. 256.

${ }^{34} \mathrm{P}$. Hauser, Tradycja i symbole narodowe jako wyraz ideologii oraz postaw politycznych Niemców w Polsce Zachodniej w latach 1919-1939 [w:] Kultura i społeczeństwo II Rzeczypospolitej, red. W. Mędrzecki, A. Zaw is zew ska, Metamorfozy Społeczne, t. 5, Warszawa 2012, s. 147-148.

${ }^{35}$ E. Alabrudzińska, Religia i polityka..., s. 160. 
z księdzem Juliuszem Burschem na czele, który bywał częstym gościem u prezydenta Ignacego Mościckiego oraz marszałka Józefa Piłsudskiego. Polscy ewangelicy udzielali wsparcia rządom sanacyjnym. Józef Ludwik Evert, prezes kolegium kościelnego warszawskiej parafii luterańskiej, był senatorem RP z listy Bezpartyjnego Bloku Współpracy z Rządem. Ewangelicy z dziada pradziada, nie rozwodnicy, byli ministrami w rządach pomajowych: Ignacy Boerner ministrem poczt i telegrafu czy Juliusz Ulrych - komunikacji ${ }^{36}$.

Władzę w Kościele sprawowali Polacy, a większość wiernych stanowili Niemcy. Ksiądz Bursche, a także część władz państwowych mieli nadzieję, że przy pomocy Polaków ewangelików uda się przyspieszyć proces polonizacji Niemców i kontrolować ich poczynania. Usiłowania te spełzły na niczym. Nastąpił natomiast, głównie w latach 30., wzrost aktywności narodowej Niemców, w tym także członków Kościoła Ewangelicko-Augsburskiego. Dochodziło do częstych konfliktów na tle narodowościowym. Toteż gdy w 1936 roku prezydent RP podpisał dekret o stosunku państwa do Kościoła Ewangelicko-Augsburskiego, dający administracji możliwość ingerencji w sprawy Kościoła, z usuwaniem ze stanowisk antypolsko nastawionych pastorów włącznie, doszło do faktycznego rozpadu Kościoła na część polską i niemiecką ${ }^{37}$. Należy podkreślić, że niemieccy ewangelicy, zarówno z kościołów unijnych, jak i ewangelicko-augsburskiego, w sporach z państwem polskim mogli liczyć na wsparcie ze strony państwa niemieckiego. Korzystając z faktu, że Polska podpisała tak zwany mały traktat wersalski dotyczący ochrony mniejszości narodowych, często słali skargi do instytucji międzynarodowych, na przykład do Ligi Narodów.

Sytuację prawną wyznawców religii mojżeszowej regulowały zarządzenia prezydenta RP z 1927 i 1928 roku powołujące Żydowski Związek Religijny grupujący 818 żydowskich gmin wyznaniowych, w których pracowało 1600 rabinów. Związek nie posiadał hierarchii duchownej, a przewidziana w rozporządzeniu Rada Religijna Gmin Żydowskich nie powstała, jej kompetencje nadzorujące przejął minister wyznań religijnych i oświecenia publicznego. Powyższe zarządzenia wraz załącznikiem określało zasady działania gmin wyznaniowych, sposoby wyboru władz, prac administracji gminnej. Należy pamiętać, że gmina były podstawowym organizatorem życia społeczności żydowskiej. Do Żydowskiego Związku Religijnego na mocy prawa musieli należeć wszyscy Żydzi, co nie do końca było zgodne z zapisanymi w konstytucji swobodami wyznaniowymi. Władze miały zagwarantowaną możliwość ingerencji w wewnętrzne sprawy gmin żydowskich, obsady urzędu rabina i nieraz z tego korzystały ${ }^{38}$. Stosunki na linii państwo - żydowskie gminy wyznaniowe układały się, szczególnie po objęciu władzy przez sanację, dość poprawnie, a marszałek Józef Piłsudski cieszył się znacznym autorytetem w środowiskach żydowskich. Był w bliskich kontaktach z rabinem wileńskim Izaakiem Rubinsztejnem ${ }^{39}$. Zdarzały się

\footnotetext{
${ }_{36}$ A. Friszke, W stulecie niepodległości-ewangelicy polscy [w:] Oniepodległości ekumenicznie..., s. $238-239$.

${ }^{37}$ T. Stegner, Polen und Deutsche in der Evangelisch-Augsburgischen Kirche in Polen (19181939) [w:] Deutsch-Polnisches Jahrbuch, Bremen 1985, s. 149-171.

${ }^{38}$ J. To mas zew ski, Niepodległa Rzeczpospolita, s. 191-192.

39 T. Stegner, Katolik, ewangelik, czy...?, s. 86.
} 
sytuacje konfliktowe, jak próba wprowadzenia w 1936 roku na drodze ustawowej zakazu uboju rytualnego zwierząt. Po wielu dyskusjach skończyło się jedynie na jego ograniczeniu ${ }^{40}$.

W granicach II RP Rzeczypospolitej istniało wiele związków wyznaniowych grupujących niewielką liczbę wiernych. Byli karaimi i muzułmanie - Tatarzy polscy; jedni i drudzy w znacznej mierze spolonizowani, zamieszkujący głównie tereny byłego Wielkiego Księstwa Litewskiego, działali w ramach Karaimskiego Związku Religijnego ${ }^{41}$ i Muzułmańskiego Związku Religijnego ${ }^{42}$. Byli staroobrzędowcy, którzy w XVII wieku odłączyli się od prawosławia. Dla nich kres rządów rosyjskich oznaczał koniec prześladowań. Rząd polski traktował staroobrzędowców jako konkurenta Cerkwi prawosławnej i starał się ich wspierać ${ }^{43}$. Muzułmanie, karaimi, staroobrzędowcy doczekali się w II RP uregulowania swojej sytuacji prawnej. Działało też kilkanaście niewielkich protestanckich związków wyznaniowych grupujących zarówno Niemców, jak i Polaków czy Ukraińców, na przykład baptystów ${ }^{44}$, stundystów, metodystów, adwentystów. $Z$ reguły były to grupy religijne prawnie nieuznawane, ale tolerowane, i mogły prowadzić działalność na podstawie ogólnych przepisów o wolności religijnej wynikających z zapisów konstytucji.

Skomplikowana była sytuacja związków wyznaniowych, które odeszły od rzymskiego katolicyzmu, takich jak na przykład Kościół mariawicki powstały na początku XX wieku. Środowiska katolickie podjęły kampanię mającą na celu ograniczenie możliwości działania czy też wręcz likwidację tegoż Kościoła. W „Przeglądzie Katolickim” czytamy: „Polska tolerując mariawityzm daje świadectwo nie tolerancji religijnej, ale zbrodni dokonywanej pod płaszczykiem religijnym, ośmiesza się, że podobne organizacje mogą istnieć na jej terytorium w XX wieku"45. Zwierzchnik Kościoła mariawitów biskup Jan Kowalski był kilkakrotnie karany wyrokami sądów państwowych za bluźnierstwa przeciwko Kościołowi katolickiemu i niemoralne postępowanie ${ }^{46}$. Władze państwowe nie zezwoliły mariawitom na działalność poza obszarem dawnego zaboru rosyjskiego, nie zakazały jednak funkcjonowania tego związku wyznaniowego mimo nacisków strony katolickiej.

${ }^{40}$ T. Zieliński, Ustawodawstwo gospodarcze Drugiej Rzeczypospolitej wymierzone w wyznawców judaizmu [w:] Metamorfozy Społeczne, t. 5, s. 262-273.

${ }^{41}$ G. Pełc zyń s k i, Najmniejsza mniejszość. Rzecz o Karaimach polskich, Warszawa 1995, s. 19-20.

42 J. Tyszkiewicz, Z historii Tatarów polskich 1794-1944, Pułtusk 2002, s. 100-153; A. Miśkiewicz, Tatarzy polscy 1918-1939. Życie spoteczno-kulturalne i religijne, Warszawa 1990, s. $77-105$.

${ }^{43}$ K. Krasowski, Związi wyznaniowe w II Rzeczypospolitej. Studium historyczno-prawne, Warszawa 1988, s. 194-196; E. I w a n i c c, Z dziejów Staroobrzędowców na ziemiach polskich, Warszawa 1977, s. 73-75.

${ }^{44}$ K. Bednarczy k, Historia Zborów Baptystów w Polsce do 1939 roku, Warszawa 1997, s. 141323.

${ }^{45}$ S. Grelew sk i, Tolerancja religijna czy tolerancja zbrodni, „Przegląd Katolicki” 1925, nr 45.

${ }^{46}$ T. Stegner, Starokatolicyzm na ziemiach polskich od lat 70. XIX wieku do II wojny światowej [w:] Biskup Franciszek Hodur. Życie - dokonania - znaczenie, red. J. Jezi er s k i, Olsztyn 2001, s. 225 245. Por. E. Warchoł, Starokatolicki Kościót Mariawitów w okresie II Rzeczypospolitej, Sandomierz 1997; K. Mazur, Mariawityzm w Polsce, Kraków 1991. 
Również przeciwko Polskiemu Narodowemu Kościołowi Katolickiemu, założonemu przez reemigrantów ze Stanów Zjednoczonych, duchowieństwo rzymskokatolickie prowadziło ostrą kampanię nie tylko propagandową, uniemożliwiając mu unormowanie swojego statusu prawnego ${ }^{47}$. Formalnie tolerowana była w Polsce działalność Badaczy Pisma Świętego, którzy między innymi z racji negatywnego stosunku do obowiązku powszechnej służby wojskowej byli narażeni na konflikty z władzami państwowymi. Wobec tak zwanych sekt religijnych w Polsce rząd II RP zajmował, jak to ujęto w memoriale Ministerstwa Wyznań Religijnych i Oświecenia Publicznego, stanowisko „nieżyczliwej neutralności”"

W wielu krajach, szczególnie w Europie Środkowo-Wschodniej, widoczne były dość istotne powiązania między przynależnością religijną i tworzącym się poczuciem świadomości narodowej ${ }^{49}$. Takie zależności możemy też obserwować na ziemiach II RP. Cechą charakterystyczną stosunków wyznaniowych w okresie międzywojennym był fakt, że podziały religijne pokrywały się często z podziałami narodowymi. W Polsce mieszkało wprawdzie 200000 Polaków ewangelików, a wśród Niemców znaczny procent $(10 \%)$ stanowili katolicy, byli Polacy bezwyznaniowcy, wyznania mojżeszowego, Ukraińcy protestanci, jednak w zdecydowanej większości Polacy byli katolikami obrządku łacińskiego, Żydzi wyznawcami religii mozaistycznej, Ukraińcy z Galicji Wschodniej grekokatolikami. Do Cerkwi prawosławnej należeli Białorusini i Ukraińcy z „ziem zabranych” i Chełmszczyzny, a większość wiernych w kościołach protestanckich stanowili Niemcy.

„Tysiącletnie węzły katolicyzmu z polskością były tak silne, że w opinii publicznej polskiej, wobec sumienia narodowego z trudnością oddziela się katolicyzm od polskości”"50 - pisał arcybiskup Kakowski. Z kolei przywódca Narodowej Demokracji Roman Dmowski twierdził: „Katolicyzm nie jest dodatkiem do polskości, ale tkwi w jego istocie"51. Stąd pojawiające się ze strony katolickiej postulaty, by nadać wyznaniu rzymskokatolickiego status religii państwowej. Arcybiskup Kakowski w odezwie wydanej z okazji rocznicy uchwalenia Konstytucji 3 maja w 1919 roku pisał: „Religia katolicka jest religią tak olbrzymiej większości, że bezwzględnie przysługiwać jej winien tytuł religii panującej i zagwarantowane być winne wszystkie jej prawa" 52 . Stereotyp Polaka-katolika wydawał się dość mocno zakorzeniony, ale nie przez wszystkie środowiska polskie akceptowany, na przykład te o liberalnej czy lewicowej proweniencji ${ }^{53}$.

${ }^{47}$ E. Warchoł, Polski Narodowy Kościót Katolicki w Polsce (1922-1952), Radom 1995, s. 29-84; K. Bi eleccki, Kościól Narodowy w Polsce w latach 1944-1965, Poznań 2003, s. 11-19.

${ }^{48}$ Cyt. za: K. Krasow s ki, op. cit., 316. Por. J. O s u chow s k i, Prawo wyznaniowe Rzeczypospolitej Polskiej 1918-1939, Warszawa 1967.

49 Por. B. Cy wińs ki, Ogniem próbowane. Korzenie tożsamości. Z dziejów najnowszych Kościoła katolickiego w Europie środkowo-wschodniej, t. I, Paryż 1982, s. 300-320; T. S te g n e r, Więź wyznaniowa a narodowa [w:] Naród i religia, red. T. S te g n e r, Gdańsk 1994, s. 6-16.

${ }^{50}$ A. Kakowski, op. cit., s. 892.

${ }_{51}$ R. D mow s ki, Kościót, naród, państwo, Warszawa 1927, s. 13.

${ }^{52}$ A. Kakowski, op. cit., s. 892.

${ }_{53}$ R. Wa pińs k i, Kształtowanie się stereotypu Polaka-katolika [w:] Naród i religia, s. 30-31. Por. B. Grott, Nacjonalizm chrześcijański, Kraków 1996, s. 18. 
Wyrazem łączności części środowisk rzymskokatolickich z nacjonalizmem był ich udział w akcjach antysemickich. Wystarczy wspomnieć niektóre czasopisma, jak chociażby „Samoobrona Narodu” księdza Stanisława Trzeciaka. Jego ataki na Żydów nazwał historyk Jerzy Kłoczowski „wręcz demonicznymi” "54. Antysemickie wypowiedzi padały także z ust najwyższych dostojników kościelnych ${ }^{55}$. Zachowania wrogie Żydom można też odnotowywać na poziomie parafii. W Wielu na Pomorzu długoletnim proboszczem był ksiądz Józef Wrycza, działacz Narodowej Demokracji. W swoich kazaniach często atakował Żydów, wzywał do bojkotu handlu żydowskiego, żądał pozbawienia ich praw politycznych. Kolportowane były pocztówki ukazujące, jak ksiądz Wrycza wygania Żydów z Wiela ${ }^{56}$. Duchowny oddziaływał na wiernych nie tylko słowem, ale i obrazem. W zbudowanej w 1928 roku Kalwarii w Wielu oprawcy Chrystusa mają wyraźnie semickie rysy, zwłaszcza nosy. Chrystus wywodzący się z rodu Dawidowego takich cech nie ma.

W okresie międzywojennym mamy do czynienia ze wzmocnieniem elementów narodowych w obrzędowości religijnej, często wprowadzanych przez duchowieństwo czy działaczy politycznych. Podczas świąt greckokatolickich w Galicji Wschodniej wywieszano ukraińskie flagi ${ }^{57}$. Kościół greckokatolicki, stając się Kościołem narodowym, znacząco przyczynił się do awansu języka ukraińskiego jako istotnego czynnika wspólnego dla wszystkich Ukraińców dziedzictwa narodowego. Jak zauważył historyk Ryszard Torzecki: „unia, obok języka i kultury, przez swój obrządek bizantyjski miała stać się również [...] czynnikiem odróżniającym Ukraińców od polskości i głębszych wpływów kultury polskiej”58. Wielu duchownych działało w ukraińskich organizacjach, także tych o wyraźnie nacjonalistycznym charakterze, co spotykało się z krytyką ze strony części duchowieństwa. „Nacjonalizm wyradza się w pogaństwo i staje się jednym z wrogów Cerkwi" "59 - pisał Osyp Nazaruk, intelektualista bliski metropolicie Andrzejowi Szeptyckiemu. Tendencje narodowe były widoczne także w postawach niektórych ukraińskich czy białoruskich duchownych prawosławnych dążących do uczynienia z Cerkwi instytucji narodowej.

Podobne zjawisko możemy obserwować wśród wielu pastorów wywodzących się z Kościołów unijnych, aktywnie działających w różnych niemieckich organizacjach, a nawet ugrupowaniach politycznych, które $\mathrm{z}$ reguły prowadziły antypolską działalność, przyczyniając się do wzrostu nastrojów nacjonalistycznych wśród ludności niemieckiej ${ }^{60}$. Duchowni Kościołów unijnych preferowali tradycyjny niemiecki

54 J. Kło czow ski, Dzieje chrześcijaństwa polskiego, Warszawa 2007, s. 308.

${ }^{55}$ Ibidem, s. 308.

${ }^{56}$ K. Kord a, Józef Wrycza (1864-1961) - ksiądz, wojak, narodowiec, Gdańsk 2013, praca doktorska napisana pod kierunkiem J. Borzykowskiego, obroniona na Uniwersytecie Gdańskim w 2013 r., s. 191194.

${ }^{57}$ S. Hor ak, Obrzędowość religijna grekokatolików w Drugiej Rzeczypospolitej [w:] Metamorfozy Społeczne, t. 5, s. 198-199.

${ }^{58}$ R. Torzecki, Kwestia ukraińska w Polsce w latach 1923-1929, Kraków 1989, s. 314; F. Rzemieniuk, Unici polscy 1596-1946, Siedlce 1998, s. 180-185.

${ }^{59}$ Cyt. za: M. Papierzyńs ka-Turek, Religia i kościót w ukraińskiej myśli politycznej w Polsce w latach 1918-1939 [w:] Polska - Polacy - mniejszości narodowe, s. 333.

${ }^{60}$ P. Hau ser, Tradycja i symbole narodowe jako wyraz ideologii..., s. 147-148. 
patriotyzm ${ }^{61}$. Wraz z rozszerzaniem się wpływów nazistowskich wśród mniejszości niemieckiej znaczenie ich w pracy narodowej znacznie zmalało, zwłaszcza wśród młodzieży zafascynowanej ideologią hitlerowską. Związek między religią a ideą narodową, także tą o syjonistycznym zabarwieniu, był silny w środowiskach żydowskich. Procesy asymilacyjne dotyczyły głównie środowisk inteligenckich i burżuazyjnych, z trudem docierały do żydowskich mas ludowych ${ }^{62}$.

II RP była państwem zachowującym wobec związków wyznaniowych zasadę równowagi we wzajemnych relacjach. Nie ulegano naciskom, głównie ze strony rzymskokatolickiej dążącej do umocnienia swojej pozycji dominującej religii, a z drugiej strony starano się zachować pokój wyznaniowy w kraju. Także struktura narodowościowo-wyznaniowa II RP sprawiała, że władze państwowe, a w znacznej mierze i szerokie kręgi społeczeństwa polskiego oceniały poszczególne związki wyznaniowe poprzez pryzmat stosunku danej mniejszości religijnej do państwa polskiego i jego interesów narodowych. Kolejne rządy, i to już od 1918 roku, starały się nie dopuścić (raczej bez powodzenia) do tego, by organizacje religijne stały się ośrodkami działalności narodowej Niemców, Ukraińców, Białorusinów - skierowanej $\mathrm{z}$ reguły przeciwko Polsce. Pragnęły także poprzez odpowiednie regulacje prawne wpływać na sprawy wewnętrzne kościołów i związków wyznaniowych mniejszości narodowych oraz przyspieszać ich ewentualną polonizację.

\section{BIBLIOGRAFIA}

\section{Źródła drukowane i wspomnienia}

D mo w ski R., Kościót, naród, państwo, Warszawa 1927.

Grelewski S., Tolerancja religijna czy tolerancja zbrodni, „Przegląd Katolicki” 1925, nr 45.

Kakowski A., Z niewoli do niepodległości. Pamiętniki, wstęp J. Glemp, red. i oprac. T. Krawczak, R. Świętek, Kraków 2000.

Konstytucja marcowa, oprac. A. Burda, Lublin 1983.

Manifest Tymczasowego Rzadu Republiki Polskiej z 7 XI 1918 r. [w:] Powstanie II Rzeczypospolitej. Wybór dokumentów, Warszawa 1981.

${ }^{61}$ P. Ha u s er, Mniejszość niemiecka w Polsce w latach 1918-1939 [w:] Polska-Polacy-mniejszości narodowe. Polska myśl polityczna XIX i XX wieku, t. VIII, red. W. Wrzes ińs ki, Wrocław 1992, s. 51.

${ }^{62} \mathrm{~K}$. Kijek, Światopoglad $i$ aspiracje życiowe ortodoksyjnej młodzieży żydowskiej $w$ Polsce międzywojennej. W stronę nowego typu ortodoksji żydowskiej w Europie Wschodniej? [w:] Metamorfozy społeczne, t. 5, s. 291-331. 


\section{Opracowania}

A labrudzińska E., Protestantyzm w Polsce w latach 1918-1939, Toruń 2004.

Alabrudzińska E., Religia i polityka. Stosunek Kościołów ewangelickich do państwa polskiego w latach 1918-1939 [w:] O niepodległości ekumenicznie. Wyznawcy różnych Kościołów dla Rzeczypospolitej (1918-1939), red. S. B ober, S. Żurek, Lublin 2018, s. $147-164$.

B ednarczyk K., Historia Zborów Baptystów w Polsce do 1939 roku, Warszawa 1997.

B i le le k i K., Kościół Narodowy w Polsce w latach 1944-1965, Poznań 2003.

B orszczewycz W., Wolyńska polityka kościelna Drugiej Rzeczypospolitej a idea wspótpracy polsko-ukraińskiej, „Biuletyn Ukrainoznawczy” 2000, nr 6.

Bujak G., Państwo a Kościoły i zwiazki wyznaniowe w II Rzeczypospolitej (1918-1939) [w:] O niepodległości ekumenicznie. Wyznawcy różnych Kościołów dla Rzeczypospolitej (1918-1939), red. S. B ober, S. Żu rek, Lublin 2018, s. 13-26.

Cywińs ki B., Ogniem próbowane. Korzenie tożsamości. Z dziejów najnowszych Kościoła katolickiego w Europie środkowo-wschodniej, t. I, Paryż 1982.

Fris zke A., W stulecie niepodległości - ewangelicy polscy [w:] O niepodległości ekumenicznie. Wyznawcy różnych Kościołów dla Rzeczypospolitej (1918-1939), red. S. B ob e r, S. Żurek, Lublin 2018, s. 238-239.

Gauden G., Lwów - kres iluzji: opowieść o pogromie listopadowym 1918 r., Kraków 2019. Grott B., Nacjonalizm chrześcijański, Kraków 1996.

Hauser P., Mniejszość niemiecka w Polsce w latach 1918-1939 [w:] Polska - Polacy mniejszości narodowe. Polska myśl polityczna XIX i XX wieku, t. VIII, red. W. Wrzesiński, Wrocław 1992.

Hauser P., Tradycja i symbole narodowe jako wyraz ideologii oraz postaw politycznych Niemców w Polsce Zachodniej w latach 1919-1939 [w:] Kultura i społeczeństwo II Rzeczypospolitej, red. W. Mędrzecki, A. Zaw is zew ska, Metamorfozy Społeczne, t. 4, Warszawa 2012, s. 39-66.

Historia Polski w liczbach, t. I, Warszawa 1994.

Horak S., Obrzędowość religijna grekokatolików w Drugiej Rzeczypospolitej [w:] Religia a społeczeństwo Drugiej Rzeczypospolitej, red. T. Stegner, Metamorfozy Społeczne, t. 5, Warszawa 2013, s. 181-200.

Iw an i e E., Z dziejów Staroobrzędowców na ziemiach polskich, Warszawa 1977.

Kijek K., Światopogląd i aspiracje życiowe ortodoksyjnej młodzieży żydowskiej w Polsce międzywojennej. W stronę nowego typu ortodoksji w Europie Wschodniej? [w:] Religia a społeczeństwo Drugiej Rzeczypospolitej, red. T. S te g n e r, Metamorfozy Społeczne, t. 5, Warszawa 2013, s. 291-332.

Kła c zkow J., Kościót Ewangelicko-Augsburski w Polsce w latach 1918-1939, Toruń 2019. Kło c zow ski J., Dzieje chrześcijaństwa polskiego, Warszawa 2007.

K o k o E., Metropolita Andrzej Szeptycki a państwo polskie [w:] Metropolita Andrzej Szeptyc$k i$, red. T. Ste gner, Gdańsk 1995.

Kołbuk W., Cerkiew prawosławna w Polsce międzywojennej, Lublin 2013.

Konstytucja marcowa, Lublin 1983.

Korda K., Józef Wrycza (1864-1961) ksiądz, wojak, narodowiec, Gdańsk 2013. Praca doktorska napisana pod kierunkiem J. Borzykowskiego, obroniona na Uniwersytecie Gdańskim w 2013 r.

Kras ows ki K., Zwiąki wyznaniowe w II Rzeczypospolitej. Studium historyczno-prawne, Warszawa 1988.

Leszczyński P., Stosunki państwo-Kościół w koncepcjach oraz praktyce rządów obozu pitsudczykowskiego, Gorzów Wielkopolski 2008. 
Mazur K., Mariawityzm w Polsce, Kraków 1991.

Mędrzecki W., Województwo wotyńskie 1921-1939. Elementy przemian cywilizacyjnych, społecznych i politycznych, Wrocław 1998.

Micew ski A., Z geografii politycznej II Rzeczpospolitej, Kraków 1966.

Mironowicz A., Prawostawni a odbudowa państwa polskiego (1918-1939) [w:] O niepodległości ekumenicznie. Wyznawcy różnych Kościołów dla Rzeczypospolitej (19181939), red. S. B ob er, S. Żurek, Lublin 2018, s. 29-43.

M iśk i ew ic z, Tatarzy polscy 1918-1939. Życie społeczno-kulturalne i religijne, Warszawa 1990.

Osuchowski J., Prawo wyznaniowe Rzeczypospolitej Polskiej 1918-1939, Warszawa 1967.

Papierzyńska-Turek M., Kościót prawosławny w Polsce w latach 1918-1927, „Dzieje Najnowsze" 1976, nr 3.

Papierzyńs ka-Tu rek M., Religia i kościót w ukraińskiej myśli politycznej w Polsce w latach 1918-1939 [w:] Polska - Polacy - mniejszości narodowe. Polska myśl polityczna XIX $i$ XX wieku, t. VIII, red. W. Wrzesiński, Wrocław 1992.

Pełczyńs ki G., Najmniejsza mniejszość. Rzecz o Karaimach polskich, Warszawa 1995.

P i la M., Udziat duchowieństwa w polskim życiu politycznym w latach 1914-1924, Lublin 1994.

Płoń ski R., Chwila sacrum w życiu prawosławia w Drugiej Rzeczypospolitej [w:] Religia a społeczeństwo Drugiej Rzeczypospolitej, red. T. Stegner, Metamorfozy Społeczne, t. 5, Warszawa 2013, s. 167-180.

Rzemieniuk F., Kościół katolicki obrządku bizantyjsko-słowiańskiego. Neounia, Lublin 1999.

Rzemieniuk F., Unici polscy 1596-1946, Siedlce 1998.

S te gner T., Józef Piłsudski: katolik, ewangelik, czy...? [w:] O niepodległości ekumenicznie. Wyznawcy różnych Kościołów dla Rzeczypospolitej (1918-1939), red. S. B ob er, S. Żu rek, Lublin 2018, s. 75-88.

Stegner T., Kościół Ewangelicko-Augsburski u zarania II Rzeczypospolitej [w:] Ewangelicy w Niepodległej, red. E. Jóźwia k, M. Kars ki, Warszawa 2018.

Stegner T., Polen und Deutsche in der Evangelisch-Augsburgischen Kirche in Polen (1918-1939) [w:] Deutsch-Polnisches Jahrbuch, Bremen 1985.

Stegner T., Starokatolicyzm na ziemiach polskich od lat 70. XIX wieku do II wojny światowej [w:] Biskup Franciszek Hodur. Życie - dokonania - znaczenie, red. J. J e zi ers k i, Olsztyn 2001.

Stegner T., Więź wyznaniowa a narodowa [w:] Naród i religia, red. T. S tegn e r, Gdańsk 1994.

Stępi eń S., Życie religijne społeczności ukraińskiej w Drugiej Rzeczypospolitej [w:] Polska-Ukraina. 1000 lat sąsiedztwa. Studia z dziejów chrześcijaństwa na pograniczu etnicznym, t. I, red. S. S tę pi eń, Przemyśl 1990.

S to p ka K., Ormianie w Polsce dawnej i dzisiejszej, Kraków 2000.

Śliw a T., Kościól greckokatolicki w Polsce w latach 1919-1939 [w:] Kościót w II Rzeczypospolitej, red. Z. Zieliński, S. Wilk, Lublin 1980.

Tomaszewski J., Niepodległa Rzeczpospolita [w:] Najnowsze dzieje Żydów w Polsce $w$ zarysie (do 1950 roku), red. J. To m a s zew ski, Warszawa 1993.

Torzecki R., Kwestia ukraińska w Polsce w latach 1923-1929, Kraków 1989.

Tys zki ew i c z J., Z historii Tatarów polskich 1794-1944, Pułtusk 2002.

Wa pińs ki R., Ksztaltowanie się stereotypu Polaka-katolika [w:] Naród i religia. Materiaty z sesji naukowej, red. T. Ste gn er, Gdańsk 1994, s. 17-33.

Warchoł E., Polski Narodowy Kościót Katolicki w Polsce (1922-1952), Radom 1995. 
Warchoł E., Starokatolicki Kościót Mariawitów w okresie II Rzeczypospolitej, Sandomierz 1997.

War s za w s k i J., Studia nad wyznaniowościa religijną marszałka Józefa Piłsudskiego, Londyn 1978.

Zieliński T., Ustawodawstwo gospodarcze Drugiej Rzeczypospolitej wymierzone w wyznawców judaizmu [w:] Religia a społeczeństwo Drugiej Rzeczypospolitej, red. T. Ste gn er, Metamorfozy Społeczne, t. 5, Warszawa 2013, s. 257-278. 